\title{
Impact of Dimensionality on Optoelectronic Properties of Hybrid Perovskites
}

\author{
Washat Ware, ${ }^{1}$ Tia Wright, ${ }^{1}$ Antony Davita, ${ }^{2}$ Evgeny Danilov, ${ }^{3}$ and Bhoj Gautam $\mathbb{D}^{1,4}$ \\ ${ }^{1}$ Department of Chemistry, Physics and Materials Science, Fayetteville State University, Fayetteville, North Carolina 28301, USA \\ ${ }^{2}$ Jack Britt High School, Fayetteville, North Carolina 28306, USA \\ ${ }^{3}$ Department of Chemistry, North Carolina State University, Raleigh, North Carolina 27695, USA \\ ${ }^{4}$ Department of Physics and Organic and Carbon Electronics Laboratory, North Carolina State University, Raleigh, \\ North Carolina 27695, USA \\ Correspondence should be addressed to Bhoj Gautam; bgautam@uncfsu.edu
}

Received 10 September 2020; Revised 25 November 2020; Accepted 17 March 2021; Published 2 April 2021

Academic Editor: Dhruba B. Khadka

Copyright (C) 2021 Washat Ware et al. This is an open access article distributed under the Creative Commons Attribution License, which permits unrestricted use, distribution, and reproduction in any medium, provided the original work is properly cited.

\begin{abstract}
Organometal halides are promising materials for photovoltaic applications, offering tunable electronic levels, excellent charge transport, and simplicity of thin-film device fabrication. Two-dimensional (2D) perovskites have emerged as promising candidates over three-dimensional (3D) ones due to their interesting optical and electrical properties. However, maximizing the power conversion efficiency is a critical issue to improve the performance of these solar cells. In this work, we studied the photophysics of a two-dimensional (2D) perovskite $\left(\mathrm{CH}_{3} \mathrm{NH}_{3}\right)_{2} \mathrm{~Pb}(\mathrm{SCN})_{2} \mathrm{I}_{2}$ thin film using steady-state and time-resolved absorption and emission spectroscopy and compared it with the three-dimensional (3D) counterpart $\mathrm{CH}_{3} \mathrm{NH}_{3} \mathrm{PbI}_{3}$. We observed a higher bandgap and faster charge recombination in $\left(\mathrm{CH}_{3} \mathrm{NH}_{3}\right)_{2} \mathrm{~Pb}(\mathrm{SCN})_{2} \mathrm{I}_{2}$ compared to $\mathrm{CH}_{3} \mathrm{NH}_{3} \mathrm{PbI}_{3}$. This work provides an improved understanding of fundamental photophysical processes in perovskite structures and provides the guideline for the design, synthesis, and fabrication of solar cells.
\end{abstract}

\section{Introduction}

Solution-processable earth-abundant three-dimensional (3D) organometal trihalide perovskites have been intensively studied due to their unique electronic and optical properties $[1,2]$. Their properties-including high charge carrier mobility, long exciton diffusion length, and low concentration of trap states, open broad prospects for their applications in a variety of industrial and technological areas including solar cells, light-emitting diodes, and field-field transistors [1-8]. Despite the high-power conversion efficiency of perovskite solar cells and high electroluminescence quantum yield of perovskite light-emitting diodes, poor long-term stability of these materials to moisture, light, and heat remains major obstacles barring widespread commercialization [9]. For this reason, identification and synthesis of alternative materials with similar optoelectronic properties are considerable.
Two-dimensional (2D) hybrid perovskites offer superior ambient stability along with local confinement, anisotropic dimensionality, and versatility of organic chemistry synthesis and flexibility for the modulation of optoelectronic properties [10-12]. Therefore, these systems are very promising alternatives to 3D perovskites for photovoltaic and lightemitting diode applications [13-19]. Most excitations in these 2D structures are excitons in contrast to free carriers in 3D perovskites and show contrasting properties compared to $3 \mathrm{D}$ structures [10]. Recently, 2D layered perovskite $\left(\mathrm{CH}_{3} \mathrm{NH}_{3}\right)_{2} \mathrm{~Pb}(\mathrm{SCN})_{2} \mathrm{I}_{2}$ has been synthesized, and power conversion efficiency (PCE), triplet generation, and device stability were examined $[12,15,20,21]$. The PCE of $\left(\mathrm{CH}_{3} \mathrm{NH}_{3}\right)_{2} \mathrm{~Pb}(\mathrm{SCN})_{2} \mathrm{I}_{2}$ solar cells is far below that of the $\mathrm{CH}_{3} \mathrm{NH}_{3} \mathrm{PbI}_{3}$ perovskite solar cells [20], and the fundamental understanding of exciton and charge generation in these $2 \mathrm{D}$ structures is still lacking. Although lead thiocyanate 
$\left(\mathrm{Pb}(\mathrm{SCN})_{2} \mathrm{I}_{2}\right)$ was used as an additive to improve the efficiency of $3 \mathrm{D}$ perovskites [22], its use as a part of a precursor to make $2 \mathrm{D}$ perovskites is very limited.

In this work, we studied the photophysics of a twodimensional (2D) perovskite $\left(\mathrm{CH}_{3} \mathrm{NH}_{3}\right)_{2} \mathrm{~Pb}(\mathrm{SCN})_{2} \mathrm{I}_{2}$ thin film using steady-state and transient spectroscopy techniques and compared it with the three-dimensional (3D) counterpart $\mathrm{CH}_{3} \mathrm{NH}_{3} \mathrm{PbI}_{3}$ to understand the photophysical processes in these perovskites. This work is focused on understanding the fundamental properties of $2 \mathrm{D}$ perovskites and identifying the factors that limit the solar cell efficiency. We observed a higher bandgap $(2.01 \mathrm{eV})$ and faster charge recombination in $\left(\mathrm{CH}_{3} \mathrm{NH}_{3}\right)_{2} \mathrm{~Pb}(\mathrm{SCN})_{2} \mathrm{I}_{2}$ compared to $\mathrm{CH}_{3} \mathrm{NH}_{3} \mathrm{PbI}_{3}$. Although the optimum bandgap photovoltaic device is $1.40 \mathrm{eV}$, there are several factors that limit the efficiency of solar cells including morphology of the active layer, charge generation and recombination, charge transfer to the interface layer, and charge transport [23-25]. In this paper, charge generation and recombination in the active layer of $\left(\mathrm{CH}_{3} \mathrm{NH}_{3}\right)_{2} \mathrm{~Pb}(\mathrm{SCN})_{2} \mathrm{I}_{2}$ and $\mathrm{CH}_{3} \mathrm{NH}_{3} \mathrm{PbI}_{3}$ perovskites are discussed.

\section{Materials and Methods}

2.1. Synthesis. Methylammonium iodide $\left(\mathrm{CH}_{3} \mathrm{NH}_{3} \mathrm{I}\right)$, lead iodide $\left(\mathrm{PbI}_{2}\right)$, lead thiocyanate $\mathrm{Pb}(\mathrm{SCN})_{2}, \mathrm{~N}, \mathrm{~N}$-dimethylformamide (DMF), dimethyl sulfoxide (DMSO), and chlorobenzene (CB) were purchased from Sigma-Aldrich. The precursor solution of $\left(\mathrm{CH}_{3} \mathrm{NH}_{3}\right)_{2} \mathrm{~Pb}(\mathrm{SCN})_{2} \mathrm{I}_{2}$ was prepared by dissolving $318 \mathrm{mg}$ of $\mathrm{CH}_{3} \mathrm{NH}_{3} \mathrm{I}$ and $323 \mathrm{mg}$ of $\mathrm{Pb}(\mathrm{SCN})_{2}$ in anhydrous DMF. $461 \mathrm{mg}$ of $\mathrm{PbI}_{2}$ and $159 \mathrm{mg}$ of $\mathrm{CH}_{3} \mathrm{NH}_{3} \mathrm{I}$ were dissolved in $1 \mathrm{~mL}$ DMF, and $78 \mu \mathrm{L}$ DMSO was added. The precursor solutions were stirred overnight at room temperature. The glass substrates were cleaned ultrasonically using deionized water, acetone, and isopropanol for $15 \mathrm{~min}$ per cleaning solvent and subsequently air dried before spin casting. Thin films were prepared by spin casting the solution on glass substrates at $5000 \mathrm{rpm}$ for 60 seconds in a glovebox with controlled nitrogen environment $(<0.5 \mathrm{ppm})$.

\subsection{Characterization}

2.2.1. X-Ray Diffraction (XRD). The XRD measurements were conducted on a Rigaku MiniFlex 600 X-ray diffractometer, and the scan range was $5-60^{\circ}$.

2.2.2. UV-Vis and Photoluminescence. Absorption measurements were carried out using a Shimadzu UV-Vis spectrometer, and steady-state photoluminescence was made using an Edinburgh Instruments FS920 fluorimeter. Time-resolved photoluminescence (TRPL) measurements were performed using a time-correlated single photon counting (TCSPC) spectrometer from Edinburgh Instruments (LifeSpec II) with a $4 \mathrm{MHz}$ variable excitation laser source. The excitation fluence was kept below $1 \mu \mathrm{J} / \mathrm{cm}^{2}$ to avoid any higher-order nonlinear processes. Morphological data were collected using a JEOL JSM-6510LV scanning electron microscope (SEM).

2.2.3. Transient Absorption. Transient absorption data were collected using transient absorption spectroscopy setup. This

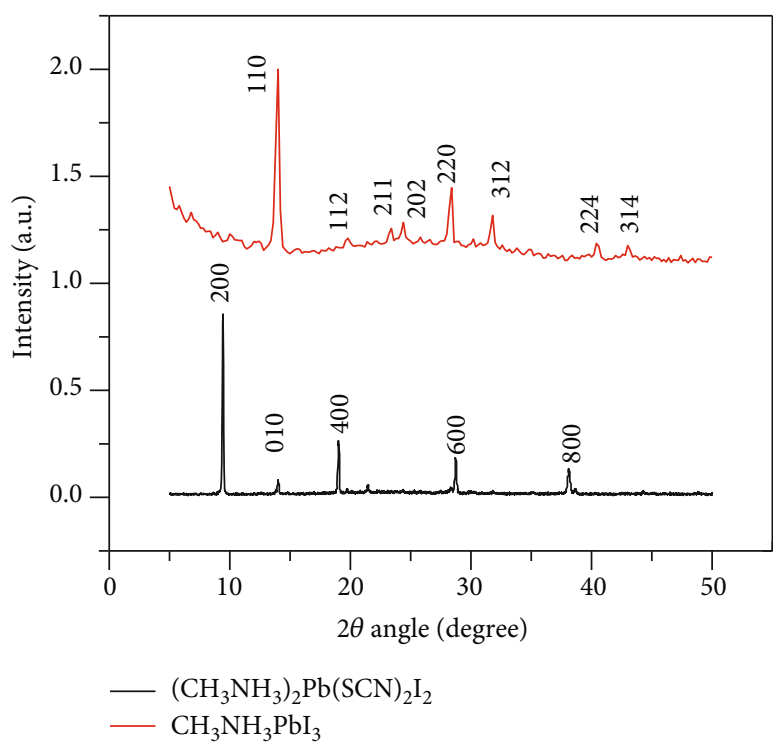

FIgure 1: XRD patterns of $\left(\mathrm{CH}_{3} \mathrm{NH}_{3}\right)_{2} \mathrm{~Pb}(\mathrm{SCN})_{2} \mathrm{I}_{2}$ (black) and $\mathrm{CH}_{3} \mathrm{NH}_{3} \mathrm{PbI}_{3}$ (red).

setup consists of the spectrometer (Ultrafast Helios System) and amplified Ti:saphhire laser. The output of amplified Ti:saphhire laser provides $800 \mathrm{~nm}$ fundamental pulses at $1 \mathrm{kHz}$ repetition rate which were split into two optical beams to generate pump and probe pulses. One fundamental beam was used to generate a pump beam using an optical parametric amplifier (OPA) system (Coherent Opera Solo). A white light probe was generated by focusing another fundamental beam into a sapphire plate. Pump and probe beams were focused on a sample, and probe light was collected by a charge-coupled device (CCD). The spectral detection region is $450 \mathrm{~nm}$ to $800 \mathrm{~nm}$. The thin-film samples were encapsulated using UV curable clue before measurement. The instrument response function (IRF) was $\sim 100$ fs FWHM. The samples were excited with the excitation energy $3.1 \mathrm{eV}$ $(400 \mathrm{~nm})$, and the fractional change in transmission was detected in the probe range $450 \mathrm{~nm}$ to $800 \mathrm{~nm}$ at several time delays.

\section{Results and Discussion}

The crystal structure of both perovskites was analyzed by XRD. Figure 1 shows the XRD patterns of $\left(\mathrm{CH}_{3} \mathrm{NH}_{3}\right)_{2} \mathrm{~Pb}(\mathrm{SCN})_{2} \mathrm{I}_{2}$ and $\mathrm{CH}_{3} \mathrm{NH}_{3} \mathrm{PbI}_{3}$ perovskite thin films in the scan range $5-60^{\circ}$. The typical peaks of both $\left(\mathrm{CH}_{3} \mathrm{NH}_{3}\right)_{2} \mathrm{~Pb}(\mathrm{SCN})_{2} \mathrm{I}_{2}$ and $\mathrm{CH}_{3} \mathrm{NH}_{3} \mathrm{PbI}_{3}$ samples are within this range. Evenly spaced characteristic peaks at $9.4^{\circ}$, $19.0^{\circ}$, and $28.8^{\circ}$ are observed in $\left(\mathrm{CH}_{3} \mathrm{NH}_{3}\right)_{2} \mathrm{~Pb}(\mathrm{SCN})_{2} \mathrm{I}_{2}$ which are assigned as [200], [400], and [600] planes and are attributed to the $\left(\mathrm{CH}_{3} \mathrm{NH}_{3}\right)_{2} \mathrm{~Pb}(\mathrm{SCN})_{2} \mathrm{I}_{2}$ phase. The peaks in both perovskites are consistent with the previously published results [26, 27]. The phase of as-synthesized $\left(\mathrm{CH}_{3} \mathrm{NH}_{3}\right)_{2} \mathrm{~Pb}(\mathrm{SCN})_{2} \mathrm{I}_{2}$ perovskite is orthorhombic at room temperature whereas it is tetragonal for $\mathrm{CH}_{3} \mathrm{NH}_{3} \mathrm{PbI}_{3}[28$, 29]. Morphology of prepared thin films was characterized using scanning electron microscopy (SEM). $\mathrm{CH}_{3} \mathrm{NH}_{3} \mathrm{PbI}_{3}$ and $\left(\mathrm{CH}_{3} \mathrm{NH}_{3}\right)_{2} \mathrm{~Pb}(\mathrm{SCN})_{2} \mathrm{I}_{2}$ thin films show the different 


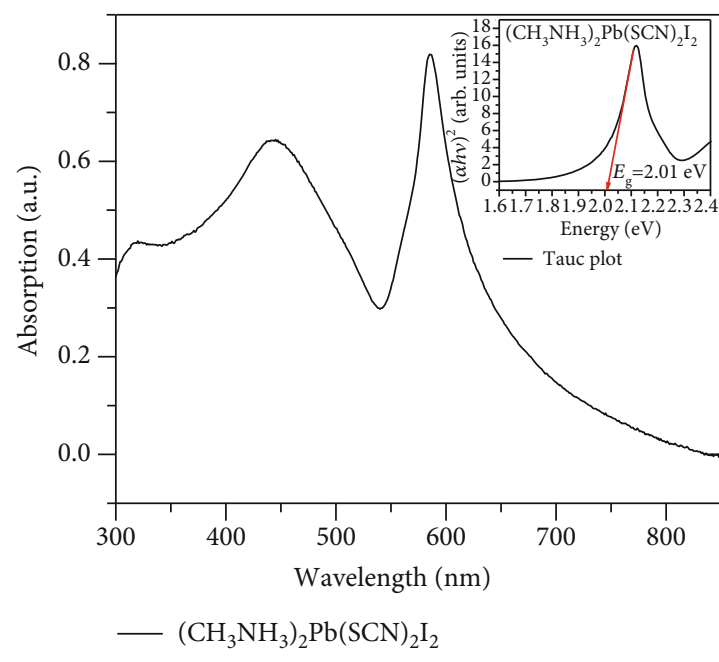

(a)

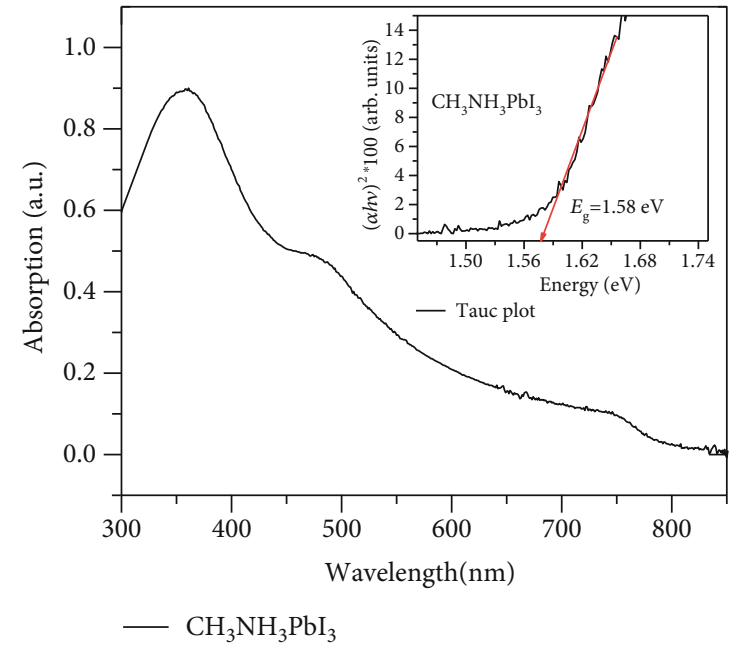

(b)

FIgURe 2: Absorption spectra of $\left(\mathrm{CH}_{3} \mathrm{NH}_{3}\right)_{2} \mathrm{~Pb}(\mathrm{SCN})_{2} \mathrm{I}_{2}$ (a) and $\mathrm{CH}_{3} \mathrm{NH}_{3} \mathrm{PbI}_{3}$ (b). Insets show the Tauc plots obtained from absorption spectra. In the inset, $\alpha$ is the absorption coefficient and $h v$ is the photon energy.

morphology. Figure S1 in supplementary file displays the SEM images of these perovskites which are similar to the images reported in the literatures. The $\mathrm{CH}_{3} \mathrm{NH}_{3} \mathrm{PbI}_{3}$ thin film shows the mesh-like structure whereas the $\left(\mathrm{CH}_{3} \mathrm{NH}_{3}\right)_{2} \mathrm{~Pb}(\mathrm{SCN})_{2} \mathrm{I}_{2}$ film has micron-size particles [27, 30, 31].

Figure 2 shows the UV-Vis absorption spectra of $\left(\mathrm{CH}_{3} \mathrm{NH}_{3}\right)_{2} \mathrm{~Pb}(\mathrm{SCN})_{2} \mathrm{I}_{2}$ and $\mathrm{CH}_{3} \mathrm{NH}_{3} \mathrm{PbI}_{3}$ perovskite thin films. The $\left(\mathrm{CH}_{3} \mathrm{NH}_{3}\right)_{2} \mathrm{~Pb}(\mathrm{SCN})_{2} \mathrm{I}_{2}$ film shows a sharp absorption peak at $586 \mathrm{~nm}(2.1 \mathrm{eV})$ which is attributed to the $1 \mathrm{~s} \mathrm{exci-}$ ton absorption. In low-dimensional systems including 2D $\left(\mathrm{CH}_{3} \mathrm{NH}_{3}\right)_{2} \mathrm{~Pb}(\mathrm{SCN})_{2} \mathrm{I}_{2}$ perovskites, there is both quantum and dielectric confinement due to the difference in permittivity between the ionic perovskite layer and the bulky organic cation [32]. These effects enhance the electron hole correlations which are manifested in absorption spectrum of these systems as a sharp excitonic peak (Figure 2). In Figure 2(a) (inset), we show the plot of $(\alpha h v)^{2}$ versus energy to obtain the correct value of bandgap of this perovskite. From extrapolation of the linear part of the Tauc plot $[33,34]$, the bandgap of $\left(\mathrm{CH}_{3} \mathrm{NH}_{3}\right)_{2} \mathrm{~Pb}(\mathrm{SCN})_{2} \mathrm{I}_{2}$ is estimated as $2.04 \mathrm{eV}$. This bandgap assignment of $\left(\mathrm{CH}_{3} \mathrm{NH}_{3}\right)_{2} \mathrm{~Pb}(\mathrm{SCN})_{2} \mathrm{I}_{2}$ is consistent with the reported values in the literature [21, 26, 30, 33, 35]. This bandgap is smaller than that of other typical single-layered $\mathrm{Pb}-\mathrm{I}$ perovskites which is likely due to the reduced confinement of inorganic sheets that are induced by the shorter spacing and octahedral tilting in the inorganic sheets [36]. The Tauc plot of the $\mathrm{CH}_{3} \mathrm{NH}_{3} \mathrm{PbI}_{3}$ film (Figure 2(b), inset) indicates that the bandgap of this perovskite is $1.58 \mathrm{eV}$ and is in close agreement with the previous reports $[18,37]$. It has been reported that incorporation of $\mathrm{SCN}^{-}$ions in $\mathrm{CH}_{3} \mathrm{NH}_{3} \mathrm{PbI}_{3}$ induces more hydrogen bonds, more distorted $\mathrm{Pb}-\mathrm{I}-\mathrm{Pb}$ bond, and shorter $\mathrm{Pb}-\mathrm{S}$ bond lengths [38] which can directly influence the band structure near the bandgap and result in higher bandgap in $\left(\mathrm{CH}_{3} \mathrm{NH}_{3}\right)_{2} \mathrm{~Pb}(\mathrm{SCN})_{2} \mathrm{I}_{2}$.

PL spectra measured using an Edinburgh Instruments FS920 fluorimeter are shown in Figure 3. We observed an emission main peak at $757 \mathrm{~nm}$ and additional low wave-

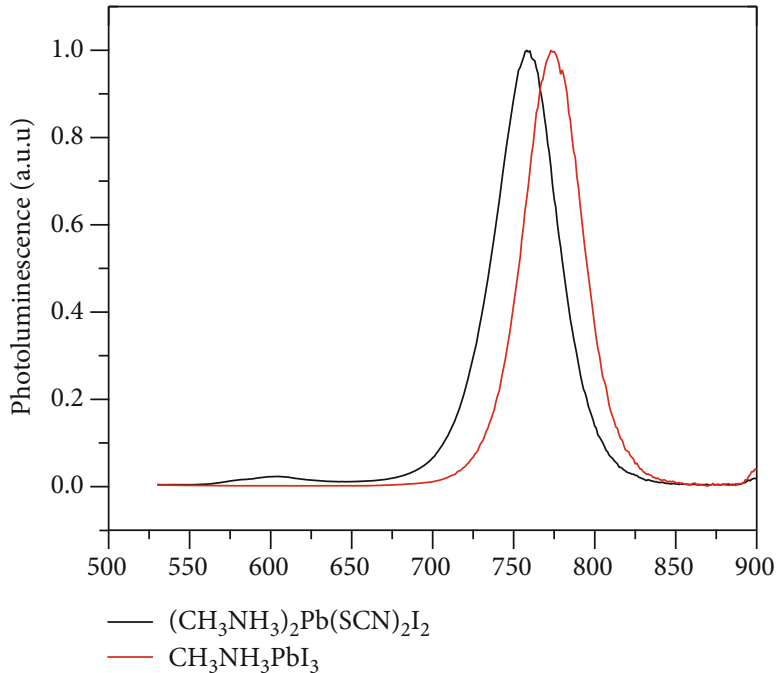

FIgURe 3: Photoluminescence spectra of $\left(\mathrm{CH}_{3} \mathrm{NH}_{3}\right)_{2} \mathrm{~Pb}(\mathrm{SCN})_{2} \mathrm{I}_{2}$ (black) and $\mathrm{CH}_{3} \mathrm{NH}_{3} \mathrm{PbI}_{3}$ (red).

length peak at $600 \mathrm{~nm}$ in $\left(\mathrm{CH}_{3} \mathrm{NH}_{3}\right)_{2} \mathrm{~Pb}(\mathrm{SCN})_{2} \mathrm{I}_{2}$. The higher energy PL peak at $600 \mathrm{~nm}$ is much weaker in intensity and is attributed to the reduced dimensionality of the layered perovskite structure. On the other hand, there is only one main emission peak at $773 \mathrm{~nm}$ in $\mathrm{CH}_{3} \mathrm{NH}_{3} \mathrm{PbI}_{3}$. The emission peaks at $757 \mathrm{~nm}$ and $600 \mathrm{~nm}$ are attributed to triplet and singlet excitons, respectively, in $\left(\mathrm{CH}_{3} \mathrm{NH}_{3}\right)_{2} \mathrm{~Pb}(\mathrm{SCN})_{2} \mathrm{I}_{2}$ whereas emission peak at $773 \mathrm{~nm}$ in $\mathrm{CH}_{3} \mathrm{NH}_{3} \mathrm{PbI}_{3}$ is due to the free carrier recombination [39]. The low-wavelength emission peak at $600 \mathrm{~nm}(2.06 \mathrm{eV})$ in $\left(\mathrm{CH}_{3} \mathrm{NH}_{3}\right)_{2} \mathrm{~Pb}(\mathrm{SCN})_{2} \mathrm{I}_{2}$ suggests that its bandgap is close to $2.06 \mathrm{eV}$ and is consistent with the bandgap estimated from the Tauc plot (Figure 1(a)). We fitted the main PL peak using the Gaussian distribution and measured the full width at half maximum (FWHM) on both films to check the color purity. The FWHM of the main peak of $\left(\mathrm{CH}_{3} \mathrm{NH}_{3}\right)_{2} \mathrm{~Pb}(\mathrm{SCN})_{2} \mathrm{I}_{2}$ perovskite is $39 \mathrm{~nm}$ whereas 


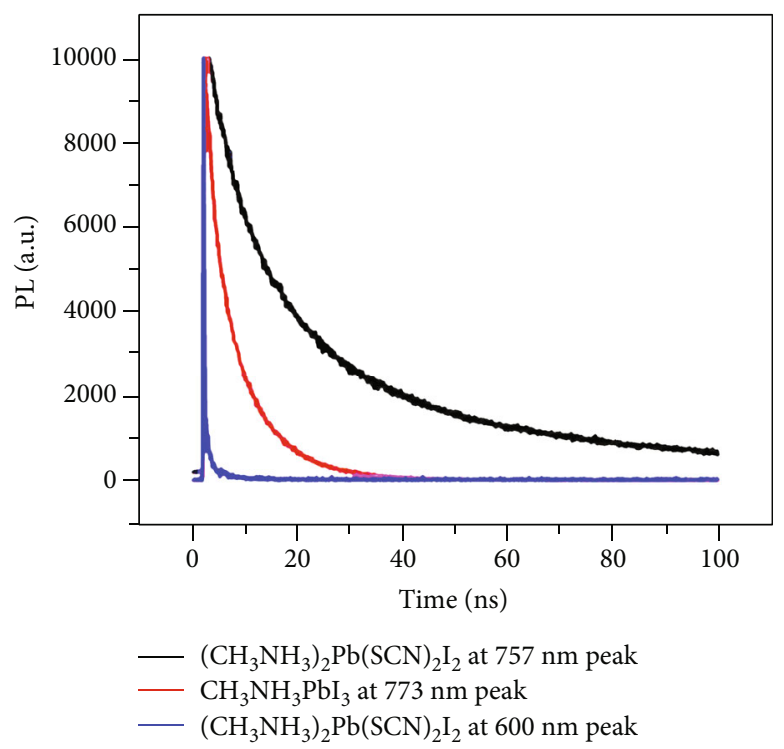

Figure 4: Photoluminescence dynamics of $\mathrm{CH}_{3} \mathrm{NH}_{3} \mathrm{PbI}_{3}$ (red) at $773 \mathrm{~nm}$ emission peak and $\left(\mathrm{CH}_{3} \mathrm{NH}_{3}\right)_{2} \mathrm{~Pb}(\mathrm{SCN})_{2} \mathrm{I}_{2}$ at $757 \mathrm{~nm}$ emission peak (black) and $600 \mathrm{~nm}$ peak (blue).

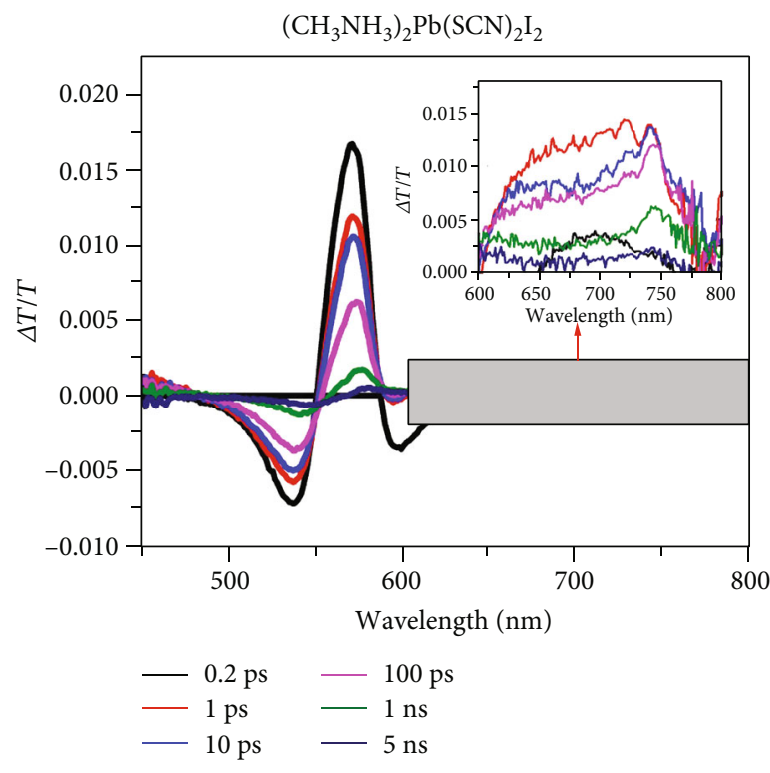

(a)

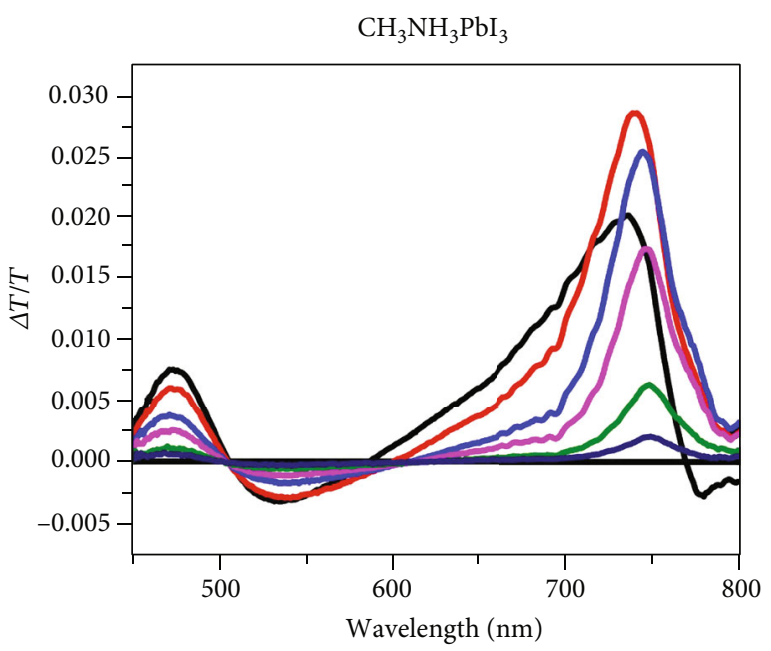

(b)

Figure 5: Transient absorption spectra of (a) $\left(\mathrm{CH}_{3} \mathrm{NH}_{3}\right)_{2} \mathrm{~Pb}(\mathrm{SCN})_{2} \mathrm{I}_{2}$ (black) and (b) $\mathrm{CH}_{3} \mathrm{NH}_{3} \mathrm{PbI}_{3}$ (red) at different time delays.

it is $36 \mathrm{~nm}$ for $\mathrm{CH}_{3} \mathrm{NH}_{3} \mathrm{PbI}_{3}$ indicating slightly better color purity in $\mathrm{CH}_{3} \mathrm{NH}_{3} \mathrm{PbI}_{3}[40,41]$. We also measured the Stokes shift in these perovskites to probe the energy loss through molecular vibrations. The Stokes shift is very similar in both perovskites $(\sim 50 \mathrm{meV})$ indicating similar vibrational energy loss.

Time-correlated single photon counting (TCSPC) was performed to measure charge/exciton dynamics. Figure 4 shows the PL dynamics of $\left(\mathrm{CH}_{3} \mathrm{NH}_{3}\right)_{2} \mathrm{~Pb}(\mathrm{SCN})_{2} \mathrm{I}_{2}$ and $\mathrm{CH}_{3} \mathrm{NH}_{3} \mathrm{PbI}_{3}$ perovskite thin films. It is interesting that the main emission peak of two perovskites exhibits contrasting PL decay dynamics. The characteristic PL lifetimes for the $\left(\mathrm{CH}_{3} \mathrm{NH}_{3}\right)_{2} \mathrm{~Pb}(\mathrm{SCN})_{2} \mathrm{I}_{2}$ main emission peak at $757 \mathrm{~nm}$, extracted by a double exponential function, are $7.5 \mathrm{~ns}$ (54\%) and $29.8 \mathrm{~ns}(46 \%)$ whereas the PL lifetimes at $600 \mathrm{~nm}$ is 220 ps. This result also confirms that the emission at $600 \mathrm{~nm}$ is due to singlet exciton while the emission at the main peak $(757 \mathrm{~nm})$ is due to triplet excitons. The observation of very short PL emission lifetime of $600 \mathrm{~nm}$ peak and long lifetime PL emission lifetime of $757 \mathrm{~nm}$ peak indicates that the recombination in $\left(\mathrm{CH}_{3} \mathrm{NH}_{3}\right)_{2} \mathrm{~Pb}(\mathrm{SCN})_{2} \mathrm{I}_{2}$ is dominated by excitonic recombination, and the $757 \mathrm{~nm}$ peak is associated with triplet excitons [19]. It has also been reported that this peak may be related to triplet excitons or defective states [19]. The characteristic PL lifetimes of $\mathrm{CH}_{3} \mathrm{NH}_{3} \mathrm{PbI}_{3}$ at $773 \mathrm{~nm}$ are $1.9 \mathrm{~ns}(56 \%)$ and $7.8 \mathrm{~ns}(44 \%)$. These results 


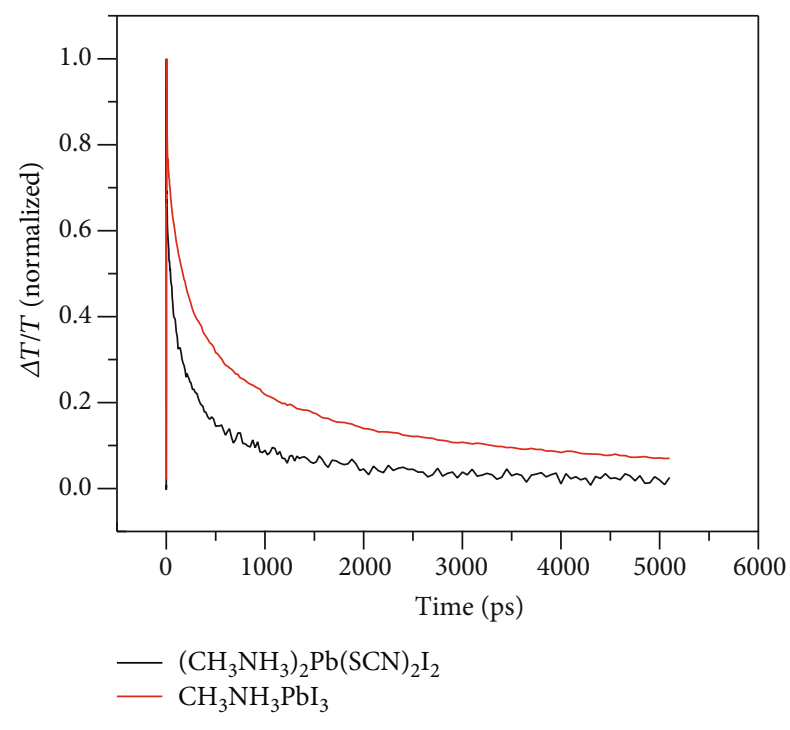

Figure 6: Transient absorption dynamics of $\left(\mathrm{CH}_{3} \mathrm{NH}_{3}\right)_{2} \mathrm{~Pb}(\mathrm{SCN})_{2} \mathrm{I}_{2}$ (black) and $\mathrm{CH}_{3} \mathrm{NH}_{3} \mathrm{PbI}_{3}$ (red) at ground state bleaching.

indicate that emissive peaks of two perovskites have contrasting lifetimes. It has been reported that radiative recombination of free electrons and holes is dominant for PL processes in $\mathrm{CH}_{3} \mathrm{NH}_{3} \mathrm{PbI}_{3}$ and the exciton model is not appropriate for this material at room temperature [42-44]. Therefore, $\mathrm{CH}_{3} \mathrm{NH}_{3} \mathrm{PbI}_{3}$ structure is different from $\left(\mathrm{CH}_{3} \mathrm{NH}_{3}\right)_{2} \mathrm{~Pb}(\mathrm{SCN})_{2} \mathrm{I}_{2}$ whose recombination dynamics is dominated by excitons $[19,45]$.

In order to monitor the exciton and charge generation dynamics, we performed femtosecond transient absorption spectroscopy (TAS) on these perovskite structures. While PL is mostly sensitive to emissive species, TAS can provide information about charges and excitons $[39,46]$. Figure 5 shows the transient absorption spectra at different time delays after the samples are excited using pump pulses tuned to $4.1 \mathrm{eV}(400 \mathrm{~nm})$. There are three different features contributing to the transient spectra. We assign the positive band to ground state bleaching (GSB) and the negative band to a photoinduced absorption (PA) $[47,48]$. We observed a sharp positive band due to GSB at $580 \mathrm{~nm}$ for $\left(\mathrm{CH}_{3} \mathrm{NH}_{3}\right)_{2} \mathrm{~Pb}(\mathrm{SCN})_{2} \mathrm{I}_{2}$ whereas this positive band for $\mathrm{CH}_{3} \mathrm{NH}_{3} \mathrm{PbI}_{3}$ is at $750 \mathrm{~nm}$. We did not observe the GSB feature of $\sim 750 \mathrm{~nm}$ in $\left(\mathrm{CH}_{3} \mathrm{NH}_{3}\right)_{2} \mathrm{~Pb}(\mathrm{SCN})_{2} \mathrm{I}_{2}$. These results clearly indicate that the bandgap of $\left(\mathrm{CH}_{3} \mathrm{NH}_{3}\right)_{2} \mathrm{~Pb}(\mathrm{SCN})_{2} \mathrm{I}_{2}$ is significantly higher than that of $\mathrm{CH}_{3} \mathrm{NH}_{3} \mathrm{PbI}_{3}$ and further supports the conclusion from UV-Vis and PL measurements. We also observed a broad weak band in the $600-800 \mathrm{~nm}$ range and is possibly due to the defects/impurities present in $\left(\mathrm{CH}_{3} \mathrm{NH}_{3}\right)_{2} \mathrm{~Pb}(\mathrm{SCN})_{2} \mathrm{I}_{2}$.

Figure 6 shows the ground state bleaching dynamics of $\left(\mathrm{CH}_{3} \mathrm{NH}_{3}\right)_{2} \mathrm{~Pb}(\mathrm{SCN})_{2} \mathrm{I}_{2}$ and $\mathrm{CH}_{3} \mathrm{NH}_{3} \mathrm{PbI}_{3}$ perovskite thin films. From biexponential data fitting, we computed the time constant of GSB dynamics. The time constants are $32 \mathrm{ps}$ (48\%) and $460 \mathrm{ps}(52 \%)$ for $\left(\mathrm{CH}_{3} \mathrm{NH}_{3}\right)_{2} \mathrm{~Pb}(\mathrm{SCN})_{2} \mathrm{I}_{2}$ and 33 ps (42\%) and 719 ps (58\%) for $\mathrm{CH}_{3} \mathrm{NH}_{3} \mathrm{PbI}_{3}$. This suggests that early dynamics for both perovskites are the same whereas the long-time components are different. Interestingly, the long-time component of $\mathrm{CH}_{3} \mathrm{NH}_{3} \mathrm{PbI}_{3}$ is higher than that of $\left(\mathrm{CH}_{3} \mathrm{NH}_{3}\right)_{2} \mathrm{~Pb}(\mathrm{SCN})_{2} \mathrm{I}_{2}$ in contrast to the PL dynamics. This suggests that the decay of radiative species monitored through PL is different from the decay photoinduced charged carriers monitored through GSB decay. The faster dynamics of GSB in $\left(\mathrm{CH}_{3} \mathrm{NH}_{3}\right)_{2} \mathrm{~Pb}(\mathrm{SCN})_{2} \mathrm{I}_{2}$ is possibly due to the defects/impurities present in $\left(\mathrm{CH}_{3} \mathrm{NH}_{3}\right)_{2} \mathrm{~Pb}(\mathrm{SCN})_{2} \mathrm{I}_{2}$.

\section{Conclusion}

In this work, we prepared $\mathrm{CH}_{3}\left(\mathrm{NH}_{3}\right)_{2} \mathrm{~Pb}(\mathrm{SCN})_{2} \mathrm{I}_{2} 2 \mathrm{D}$ perovskite and $\mathrm{CH}_{3} \mathrm{NH}_{3} \mathrm{PbI}_{3} 3 \mathrm{D}$ perovskites. Using steady-state and transient absorption and emission spectroscopies, we studied the exciton and charge generation in these structures. We observed a higher bandgap and faster charge recombination in $\left(\mathrm{CH}_{3} \mathrm{NH}_{3}\right)_{2} \mathrm{~Pb}(\mathrm{SCN})_{2} \mathrm{I}_{2}$ compared to the $\mathrm{CH}_{3} \mathrm{NH}_{3} \mathrm{PbI}_{3}$. In addition, excitonic recombination is dominant in PL decay (decay of radiative species) of $\left(\mathrm{CH}_{3} \mathrm{NH}_{3}\right)_{2} \mathrm{~Pb}(\mathrm{SCN})_{2} \mathrm{I}_{2}$ whereas it is free carrier recombination in $\mathrm{CH}_{3} \mathrm{NH}_{3} \mathrm{PbI}_{3}$. We also observed the presence of defects/impurities in $\left(\mathrm{CH}_{3} \mathrm{NH}_{3}\right)_{2} \mathrm{~Pb}(\mathrm{SCN})_{2} \mathrm{I}_{2}$, as evidenced by transient absorption spectra. The low power conversion efficiency of $\left(\mathrm{CH}_{3} \mathrm{NH}_{3}\right)_{2} \mathrm{~Pb}(\mathrm{SCN})_{2} \mathrm{I}_{2}$ solar cells compared to that of $\mathrm{CH}_{3} \mathrm{NH}_{3} \mathrm{PbI}_{3}$ is possibly due to the faster charge recombination as observed in TAS. This study will greatly facilitate fundamental understanding of structure-property relations in the hybrid perovskite structures.

\section{Data Availability}

The data used to support the findings of this study are available from the corresponding author upon request.

\section{Conflicts of Interest}

The authors declare that they have no conflicts of interest.

\section{Acknowledgments}

This work is supported by NSF PREM in collaboration with the Center for High Resolution Neutron Scattering (CHRNS) through award DMR 1827731. Dr. Zhiping Luo and Dr. Gibin George from Fayetteville State University are acknowledged for providing the supplies through IMREL facility, and Dr. Rachel Wells is acknowledged for helping in SEM image measurements. Dr. David Hoogerheide, Dr. Julie Borchers, and Dr. Dan Neumann at the National Institute of Standards and Technology (NIST) Center for Neutron Research are acknowledged for the fruitful discussion in the project.

\section{Supplementary Materials}

Figure $\mathrm{S} 1$. SEM images of (a) $\left(\mathrm{CH}_{3} \mathrm{NH}_{3}\right)_{2} \mathrm{~Pb}(\mathrm{SCN})_{2} \mathrm{I}_{2}$ and (b) $\mathrm{CH}_{3} \mathrm{NH}_{3} \mathrm{PbI}_{3}$ thin films. (Supplementary Materials)

\section{References}

[1] G. E. Eperon, S. D. Stranks, C. Menelaou, M. B. Johnston, L. M. Herz, and H. J. Snaith, "Formamidinium lead trihalide: a 
broadly tunable perovskite for efficient planar heterojunction solar cells," Energy \& Environmental Science, vol. 7, no. 3, pp. 982-988, 2014.

[2] E. Mosconi, P. Umari, and F. De Angelis, "Electronic and optical properties of $\mathrm{MAPbX}_{3}$ perovskites $(\mathrm{X}=\mathrm{I}, \mathrm{Br}, \mathrm{Cl})$ : a unified DFT and GW theoretical analysis," Physical Chemistry Chemical Physics, vol. 18, no. 39, pp. 27158-27164, 2016.

[3] Z. K. Tan, R. S. Moghaddam, M. L. Lai et al., "Bright LightEmitting Diodes based on Organometal Halide Perovskite," Nature Nanotechnology, vol. 9, no. 9, pp. 687-692, 2014.

[4] S. P. Senanayak, B. Yang, T. H. Thomas et al., "Understanding charge transport in lead iodide perovskite thin-film field-effect transistors," Science Advances, vol. 3, no. 1, article e1601935, 2017.

[5] S. D. Stranks, G. E. Eperon, G. Grancini et al., "Electron-hole diffusion lengths exceeding 1 micrometer in an organometal trihalide perovskite absorber," Science, vol. 342, no. 6156, pp. 341-344, 2013.

[6] Y. Liu, S. Akin, L. Pan et al., "Ultrahydrophobic 3D/2D fluoroarene bilayer-based water-resistant perovskite solar cells with efficiencies exceeding 22\%," Science Advances, vol. 5, no. 6, article eaaw2543, 2019.

[7] D. B. Khadka, Y. Shirai, M. Yanagida, and K. Miyano, "Ammoniated aqueous precursor ink processed copper iodide as hole transport layer for inverted planar perovskite solar cells," Solar Energy Materials \& Solar Cells, vol. 210, article 110486, 2020.

[8] D. B. Khadka, Y. Shirai, M. Yanagida, and K. Miyano, "Unraveling the impacts induced by organic and inorganic hole transport layers in inverted halide perovskite solar cells," ACS Applied Materials \& Interfaces, vol. 11, no. 7, pp. 70557065, 2019.

[9] T. P. Gujar, T. Unger, A. Schönleber et al., "The role of $\mathrm{PbI}_{2}$ in $\mathrm{CH}_{3} \mathrm{NH}_{3} \mathrm{PbI}_{3}$ perovskite stability, solar cell parameters and device degradation," Physical Chemistry Chemical Physics, vol. 20, no. 1, pp. 605-614, 2018.

[10] Q. Zhang, L. Chu, F. Zhou, W. Ji, and G. Eda, "Excitonic properties of chemically synthesized $2 \mathrm{D}$ organic-inorganic hybrid perovskite nanosheets," Advanced Materials, vol. 30, no. 18, article 1704055, 2018.

[11] T. He, S. Li, Y. Jiang et al., "Reduced-dimensional perovskite photovoltaics with homogeneous energy landscape," Nature Communications, vol. 11, no. 1, article 1672, 2020.

[12] Y. H. Chiang, H. M. Cheng, M. H. Li, T. F. Guo, and P. Chen, "Low-pressure vapor-assisted solution process for thiocyanate-based pseudohalide perovskite solar cells," ChemSusChem, vol. 9, no. 18, pp. 2620-2627, 2016.

[13] L. L. Lei, D. Seyitliyev, S. Stuard et al., "Efficient energy funneling in quasi-2D perovskites: From light emission to lasing," Advanced Materials, vol. 32, no. 16, article 1906571, 2020.

[14] P. Li, C. Liang, X. L. Liu et al., "Perovskite Solar Cells: LowDimensional Perovskites with Diammonium and Monoammonium Alternant Cations for High-Performance Photovoltaics," Advanced Materials, vol. 31, no. 35, article 1970252, 2019.

[15] Y. Numata, Y. Sanehira, R. Ishikawa, H. Shirai, and T. Miyasaka, "Thiocyanate containing two-dimensional cesium lead iodide perovskite, $\mathrm{Cs}_{2} \mathrm{PbI}_{2}(\mathrm{SCN})_{2}$ : Characterization, photovoltaic application, and degradation mechanism," ACS Applied Materials \& Interfaces, vol. 10, no. 49, pp. 42363-42371, 2018.
[16] M. D. Smith, B. A. Connor, and H. I. Karunadasa, "Tuning the luminescence of layered halide perovskites," Chemical Reviews, vol. 119, no. 5, pp. 3104-3139, 2019.

[17] Z. Zhang, Y. Zhou, Y. Cai et al., "Efficient and stable $\mathrm{CH}_{3} \mathrm{NH}_{3} \mathrm{PbI}_{3-\mathrm{x}}(\mathrm{SCN})_{\mathrm{x}}$ planar perovskite solar cells fabricated in ambient air with low-temperature process," Journal of Power Sources, vol. 377, pp. 52-58, 2018.

[18] J. C. Blancon, H. Tsai, W. Nie et al., "Extremely efficient internal exciton dissociation through edge states in layered 2D perovskites," Science, vol. 355, no. 6331, pp. 1288-1292, 2017.

[19] C. H. Li, C. C. Tsai, M. Y. Liao, Y. A. Su, S. T. Lin, and C. C. Chueh, "Stable, color-tunable 2D SCN-based perovskites: revealing the critical influence of an asymmetric pseudohalide on constituent ions," Nanoscale, vol. 11, no. 6, pp. 2608-2616, 2019.

[20] L. Guo, O. Wang, D. Zhao, X. Gan, and H. Liu, "The Deposition of $\left(\mathrm{CH}_{3} \mathrm{NH}_{3}\right)_{2} \mathrm{~Pb}(\mathrm{SCN})_{2} \mathrm{I}_{2}$ thin films and their application in perovskites solar cells," Polyhedron, vol. 145, pp. 16-21, 2018.

[21] R. Younts, H. S. Duan, B. Gautam et al., "Efficient generation of long-lived triplet excitons in 2D Hybrid perovskite," Advanced Materials, vol. 29, no. 9, p. 1604278, 2017.

[22] Y. Yu, C. Wang, C. R. Grice et al., "Improving the performance of formamidinium and cesium lead triiodide perovskite solar cells using lead thiocyanate additives," ChemSusChem, vol. 9, no. 23, pp. 3288-3297, 2016.

[23] F. Zhang, D. H. Kim, H. Lu et al., "Enhanced charge transport in 2D perovskites via fluorination of organic cation," Journal of the American Chemical Society, vol. 141, no. 14, pp. 59725979, 2019.

[24] Z. Zhang, W. H. Fang, R. Long, and O. V. Prezhdo, "Exciton dissociation and suppressed charge recombination at $2 \mathrm{D}$ perovskite edges: key roles of unsaturated halide bonds and thermal disorder," Journal of the American Chemical Society, vol. 141, no. 39, pp. 15557-15566, 2019.

[25] J. Cho, J. T. DuBose, and P. V. Kamat, "Charge carrier recombination dynamics of two-dimensional lead halide perovskites," Journal of Physical Chemistry Letters, vol. 11, no. 7, pp. 2570-2576, 2020.

[26] J. G. Labram, N. R. Venkatesan, C. J. Takacs et al., "Charge transport in a two-dimensional hybrid metal halide thiocyanate compound," Journal of Materials Chemistry C, vol. 5, no. 24, pp. 5930-5938, 2017.

[27] G. Rajendra Kumar, A. Dennyson Savariraj, S. N. Karthick et al., "Phase transition kinetics and surface binding states of methylammonium lead iodide perovskite," Physical Chemistry Chemical Physics, vol. 18, no. 10, pp. 7284-7292, 2016.

[28] Y. Dang, G. Liu, J. Song et al., "Layered Perovskite $\left(\mathrm{CH}_{3} \mathrm{NH}_{3}\right)_{2} \mathrm{~Pb}(\mathrm{SCN})_{2} \mathrm{I}_{2}$ Single crystals: Phase transition and moisture stability," ACS Applied Materials \& Interfaces, vol. 12, no. 33, pp. 37713-37721, 2020.

[29] P. S. Whitfield, N. Herron, W. E. Guise et al., "Structures, phase transitions and tricritical behavior of the hybrid perovskite methyl ammonium lead iodide," Scientific Reports, vol. 6, no. 1, article 35685, 2016.

[30] M. I. Alturisa, J. Wira, Mardiyati, Herman, and R. Hidayat, "Influences of precursor solution concentration and temperature on $\mathrm{CH} 3 \mathrm{NH} 3 \mathrm{PbI} 3$ Perovskite Layer Morphology and the unconverted PbI2Proportion to their perovskite solar cell Characteristics," Journal of Physics: Conference Series, vol. 877, article 012046, 2017. 
[31] Q. Jiang, D. Rebollar, J. Gong, E. L. Piacentino, C. Zheng, and T. $\mathrm{Xu}$, "Pseudohalide-Induced Moisture Tolerance in Perovskite $\mathrm{CH}_{3} \mathrm{NH}_{3} \mathrm{~Pb}(\mathrm{SCN})_{2} \mathrm{I}$ Thin Films," Angewandte Chemie International Edition, vol. 54, no. 26, pp. 7617-7620, 2015.

[32] A. Burgos-Caminal, E. Socie, M. E. F. Bouduban, and J. E. Moser, "Exciton and carrier dynamics in two-dimensional perovskites," Journal of Physical Chemistry Letters, vol. 11, no. 18, pp. 7692-7701, 2020.

[33] Z. Xiao, W. Meng, B. Saparov et al., "Photovoltaic properties of two-dimensional $\left(\mathrm{CH}_{3} \mathrm{NH}_{3}\right)_{2} \mathrm{~Pb}(\mathrm{SCN})_{2} \mathrm{I}_{2}$ perovskite: a combined experimental and density functional theory study," Journal of Physical Chemistry Letters, vol. 7, no. 7, pp. 1213-1218, 2016.

[34] S. Chatterjee and A. J. Pal, "Introducing $\mathrm{Cu}_{2} \mathrm{O}$ thin films as a hole-transport layer in efficient planar perovskite solar cell structures," Journal of Physical Chemistry C, vol. 120, no. 3, pp. 1428-1437, 2016.

[35] J. I. Clavijo Penagos, E. R. Romero, G. Gordillo, J. M. Correa Hoyos, and M. Á. Reinoso Sánchez, "On the True Band Gap of the $\left(\mathrm{CH}_{3} \mathrm{NH}_{3}\right)_{2} \mathrm{~Pb}(\mathrm{SCN})_{2} \mathrm{I}_{2}$ Hybrid Perovskite: An Interesting Solar-Cell Material," Physica Status Solidi RRL: Rapid Research Letters, vol. 12, no. 4, article 1700376, 2018.

[36] D. Umeyama, Y. Lin, and H. I. Karunadasa, "Red-to-black piezochromism in a compressible $\mathrm{Pb}-\mathrm{I}-\mathrm{SCN}$ layered perovskite," Chemistry of Materials, vol. 28, no. 10, pp. 3241-3244, 2016.

[37] D. Marongiu, M. Saba, F. Quochi, A. Mura, and G. Bongiovanni, "The role of excitons in 3D and 2D lead halide perovskites," Journal of Materials Chemistry C, vol. 7, no. 39, pp. 12006-12018, 2019.

[38] G. Tang, C. Yang, A. Stroppa, D. Fang, and J. Hong, "Revealing the role of thiocyanate anion in layered hybrid halide perovskite $\left(\mathrm{CH}_{3} \mathrm{NH}_{3}\right)_{2} \mathrm{~Pb}(\mathrm{SCN})_{2} \mathrm{I}_{2}$," The Journal of Chemical Physics, vol. 146, no. 22, p. 224702, 2017.

[39] J. S. Manser and P. V. Kamat, "Band filling with free charge carriers in organometal halide perovskites," Nature Photonics, vol. 8, no. 9, pp. 737-743, 2014

[40] G. C. Adhikari, P. A. Vargas, H. Zhu, A. Grigoriev, and P. Zhu, "Tetradic phosphor white light with variable CCT and superlative CRI through organolead halide perovskite nanocrystals," Nanoscale Advances, vol. 1, no. 5, pp. 1791-1798, 2019.

[41] G. C. Adhikari, S. Thapa, H. Zhu, and P. Zhu, " $\mathrm{Mg}^{2+}$-alloyed all-inorganic halide perovskites for white light-emitting diodes by 3D-printing method," Advanced Optical Materials, vol. 7, no. 20, article 1900916, 2019.

[42] Y. Yamada, T. Nakamura, M. Endo, A. Wakamiya, and Y. Kanemitsu, "Photocarrier recombination dynamics in perovskite $\mathrm{CH}_{3} \mathrm{NH}_{3} \mathrm{PbI}_{3}$ for solar cell applications," Journal of the American Chemical Society, vol. 136, no. 33, pp. 11610-11613, 2014.

[43] L. M. Herz, "Charge-carrier dynamics in organic-inorganic metal halide perovskites," Annual Review of Physical Chemistry, vol. 67, no. 1, pp. 65-89, 2016.

[44] T. Kirchartz, J. A. Márquez, M. Stolterfoht, and T. Unold, "Photoluminescence-based characterization of halide perovskites for photovoltaics," Advanced Energy Materials, vol. 10, no. 26, p. 1904134, 2020.

[45] R. Younts, E. Danilov, K. Gundogdu, and B. Gautam, "Charge generation dynamics in polymer nonfullerene solar cells with low energy loss," Journal of Photonics for Energy, vol. 8, no. 3 , article $032209,2018$.
[46] Y. Zhai, C. X. Sheng, C. Zhang, and Z. V. Vardeny, "Ultrafast spectroscopy of photoexcitations in organometal trihalide perovskites," Advanced Functional Materials, vol. 26, no. 10, pp. 1617-1627, 2016.

[47] B. Anand, S. Sampat, E. O. Danilov et al., "Broadband transient absorption study of photoexcitations in lead halide perovskites: Towards a multiband picture," Physical Review B, vol. 93, no. 16, p. 161205, 2016.

[48] Z. Xiao, W. Meng, J. Wang, and Y. Yan, "Defect properties of the two-dimensional $\left(\mathrm{CH}_{3} \mathrm{NH}_{3}\right)_{2} \mathrm{~Pb}(\mathrm{SCN})_{2} \mathrm{I}_{2}$ perovskite: a density-functional theory study," Physical Chemistry Chemical Physics, vol. 18, no. 37, pp. 25786-25790, 2016. 